\title{
ANTTONEN, VEIKKO
}

\section{A REFORMÁCIÓ HATÁSAI A GONDOLKODÁSMÓD ÉS ERKÖLCS KIALAKULÁSÁRA A SKANDINÁV TÉRSÉG ORSZÁGAIBAN}

\section{Bevezetés}

A protestáns világ más részeihez hasonlóan a skandináv térség országai ${ }^{1}$ is megemlékeztek 2017. október 31-én a reformáció ötszáz éves évfordulójáról. Habár az elmúlt évtizedekben nagymértékben visszaesett az evangélikus-lutheránus egyházak követőinek száma a skandináv államokban, a lutheri tanok továbbra is jelen vannak a skandináv erkölcsiségben. A finnországi Evangélikus- Lutheránus Egyház Kutatóközpontja időről időre Gallup Ecclesiastica címmel közvélemény-kutatást végez azzal a céllal, hogy empirikus adatokat gyüjtsön a lutheránus értékekről és erkölcsről. Az intézmény által 2015-ben, „Elhivatott lutheranizmus” címmel megjelentetett felmérésben 419415 és 79 év közötti személyt kérdeztek meg azért, hogy megállapítsák, milyen módon van jelen napjainkban a finn lakosság körében a lutheránus erkölcsiség és milyen módon őrződtek meg a lutheranizmusból eredő értékek és látásmódok. A kutatók arra voltak kíváncsiak, hogy a technikai fejlődés közepette a vallásosságtól elfordult modern világunkban az emberek vajon még mindig magukénak vallják-e ezeket az értékeket. Jelen tanulmányomban nem ennek a felmérésnek az eredményeivel szeretnék foglalkozni elsősorban, hanem inkább azzal, hogy milyen hatással volt a lutheri reformáció a skandináv gondolkodásmód és erkölcsiség kialakulására.

Az említett Gallup Ecclesiastica elnevezésủ közvélemény-kutatás finnországi eredményei szerint, a lutheránus erkölcs igenis tetten érhető a mai modern világban. Jelen van abban, ahogyan az emberek a másokról való gondoskodásról és a társadalom tagjainak egymás iránt érzett felelösségéről vélekednek. Megnyilvánulnak ezek az értékek abban is, hogy az emberek úgy tartják, Isten gondot visel ránk ebben a földi világban egyszerủ hétköznapi életünkön keresztül, valamint abban is, hogy az emberek a munkát hivatásnak, mi több kötelességnek tekintik. Továbbá pedig abban is megragadható ez

\footnotetext{
${ }^{1}$ A forditó megjegyzése: Az angol szóhasználat a magyarral ellentétben különbséget tesz a Scandinavian és a Nordic jelzők között: az előbbit angolul rendszerint csak Norvégia, Svédország és Dánia jelölésére szokás használni, míg az utóbbi Finnországot is tartalmazza. A magyar szóhasználatban azonban szövegkörnyezettől függően a skandináv szó jelölheti Finnországot is. Mivel az északi országok kifejezés a magyarban nem honosodott meg, azért a fordításban többnyire a skandináv ill. a skandináv térség országai megfogalmazást választottam és értve alatta Finnországot, valamint a korábban finnek által lakott területeket is. Az eredeti tanulmány nem tartalmazza a Scandinavian jelzőt.
} 
az erkölcsiség, hogy a gyermekek nevelésében a keresztény értékeket hangsúlyozzák és himnuszok, énekek révén is kifejezésre juttatják ezt a szellemiséget (Ketola et al. 2017). Tudományos szemszögből sokkal érdekesebb a lutheránus tanok iránti elkötelezettség kérdését vizsgálni akkor, ha nem annyira a lutheránus értékekkel kapcsolatos személyes beállítottság kvantitatív adatait helyezzük a középpontba. Érdekesebb, ha inkább arra irányítjuk figyelmünket, hogy milyen hatással volt a lutheri reformáció a skandináv térség országaira jellemző gondolkodásmód és erkölcsi világ kialakulásában. Elsőként megállapítható, hogy a lutheri értékrend az elmúlt ötszáz évben a skandináv nemzetek számára nyilvánvalóan fontos szerepet játszott. A skandináv országokban a lutheránus egyházak szétválaszthatatlanul összefonódtak a nemzettudat kialakulásával annak köszönhetően, hogy megteremtettek egy olyan vallásos gondolatvilágot, mely szorosan összefügg az állampolgárságról alkotott felfogásokkal s melynek értelmében az emberek egyaránt részei az egyháznak és a nemzetnek. Ugyanakkor a skandináv társadalmakban az egyház nem a reformáció révén jutott meghatározó hatalomhoz a népéletben. A társadalmi berendezkedésre gyakorolt egyházi befolyás az ezt megelőző katolikus időszakban is tapasztalható volt. A reformáció elött a középkori népi kultúrában az egyház mindenre kiterjedő hatalommal bírt azáltal, hogy az évenként ismétlődő egyházi ünnepek, az élet jelentős eseményeihez kapcsolódó rituálék meghatározták az emberek életét, továbbá az egyház szabta meg azokat az erkölcsi normákat, melyhez a köznép tagjai saját viselkedésüket és a hétköznapi életben meghozott különféle döntéseiket igazították (lásd: Talve 1997:234). A reformáció ugyanakkor hatalmas jelentőségü esemény volt a skandináv társadalmak történetében, ha annak az egyén gondolkodásmódjára és erkölcsére gyakorolt hatását vizsgáljuk. A vallásosság átértelmeződése azonban soha sem egyenes irányú folyamat, hanem azt „ellentétes erők egymásnak feszülése, ütközése és összecsapása irányítja” (Goldstein 2009:158.). I. Gusztáv király (1521/23-1560), a Vasa dinasztia megalapítója indította útjára a svédek és finnek lakta területeken a reformációt, az újfajta vallásosság elterjedése pedig inkább tekinthető politikai, mintsem egyházi átalakulásnak. A reformációnak központi szerepe volt abban, hogy létrejött az a skandináv világi társadalom, melynek polgárai az állammal és az egyházzal szemben egyaránt hűséggel és engedelmességgel viseltetnek. 2018-ban még mindig 65 és 80 százalék közötti azon lakosok száma, akik az adott ország evangélikus-lutheránus egyházához tartoznak.

\section{Európa vallásos egységének felbomlása}

A protestáns reformáció hatalmas jelentőségű hatást gyakorolt Európa történelmi fejlödésére az elmúlt ötszáz év során. Nincs másik olyan esemény az európai történelemben, amelyet olyan széles körű érdeklődés kísért volna, mint azt, ami 1517. október 31-én egy erődként is szolgáló komor egyetemi városban, Wittenbergben történt. Az európai történelem új korszakát indította el az a puszta kézzel papírra vetett 95 pontból álló 
tételsor, amely megkérdőjelezte a középkori katolikus egyház tanait és gyakorlatait. A jól ismert történet szerint Luther Márton Ágoston-rendi szerzetes és egyetemi tanár azzal vonult be a teológia történetébe, hogy 95 tézisét a wittenbergi vártemplom kapujára kiszögezte. Az események helyszíne azonban nem csupán egy vallásos tér volt, hanem egyben egy olyan hely is, ahol tudományos tanácskozásokat tartottak. Luther Mártonról írt új életrajzi munkájában Lyndal Roper történész úgy véli, a reformátornak kezdetben nem állt szándékában, hogy vallási megújulást indítson útjára, helyette valójában mindössze tudományos vitát kezdeményezett (Roper 2016: 2). Soha nem volt olyan szándéka, hogy a vitairatot megjelentessék vagy, hogy azokat egy maréknyi tudóson kívül széles körben bárki is elolvassa (Roper 2016: 96). Az, hogy valóban kiszögezte-e 95 pontból álló tételsorát a kapura, szintén csak mendemonda és nem bizonyítható. A tudományos vitára aztán - igaz, hogy két évvel később és szűk körben -, de végül csak sor került. Johannes Eck 1519 júniusában, Lipcsében nyilvánosan megvitatta Lutherrel az említett tételeket (Roper 2016: 125). Biztosan tudható, hogy Luther a nyilvánosságra hozatal előtt a kézzel írt tételeket két személynek küldte el levélben, az egyik Albrecht mainzi érsek volt, a másik pedig a brandenburgi püspök. A tételek ismertetésének időzítése valószínűleg kapcsolódott Mindenszentekhez ünnepéhez, amely időszakban Frigyes szász választófejedelem, aki egyben Luther uralkodója is volt, a wittenbergi vártemplomban állította ki lenyűgöző ereklyegyűjteményt. A választófejedelem ereklyegyüjteményének darabjait azért tették közszemlére a vártemplomhoz tartozó kolostorban, hogy Szászország szent zarándokhellyé váljon és az embereknek pedig ne kelljen útra kelniük Rómába és ne ott költsék el a pénzüket. A római zarándoklat helyett hazai földön kaphattak isteni kegyelmet pénzükért. Messzi földről érkeztek zarándokok azért, hogy megemlékezzenek Mindenszentek ünnepéről és búcsúcédulát vásároljanak azért, hogy megmeneküljenek a tisztítótűztől. Vallásos gyakorlat volt akkoriban, hogy az emberek a bủnbocsánatot megvásárolták, ami pedig a bünbánat teológiai fontosságának olyan félreértése volt, amely ellen Luther szót emelt javaslataival. Luther szerint az ember csak az isteni kegyelem révén, sola gratia, és nem cselekedetei alapján üdvözülhet. A wittenbergi kolostor, ahová Luther 1511-ben 27 évesen lépett be, a reformátor számára az áhítatosság helye volt. Miután 1505-ben belépett a rendbe Lutherre nagy hatással volt a meghatározó Ágoston-rendi teológus Johann von Staupitz, aki tevékeny részt vállalt abban, hogy az új egyetem létrejöhessen (Roper 2006:7). Bölcs Frigyes, aki 1502-ben megalapította az egyetemet, tudatosan ugyanis arra törekedett, hogy az Ágoston-rendi kolostort később egy tudományos intézménnyé alakítsa úgy, hogy ott majd a rend tagjai fognak oktatni (Roper 2016: 77). Megérkezése után egy évvel, 1512-ben Luther doktori fokozatot szerzett és kinevezték a teológia professzorának. Amikor a 95 tételt nyilvánosságra hozta, Luther 33 éves volt és immár tizenkét éve szolgált szerzetesként. (Roper 2016: 4-5; 81-83.)

A reformáció a vallásos egység felbomlását hozta magával Európában. Az európai identitás kialakulásának meghatározó mozzanata volt a keresztény hit általános megtartása. A felekezeti sokszínűség megjelenése indította el viszont azt a folyamatot, 
melynek eredményeként létrejött a modern, művelt és felfogásában racionális Európa. A történészek és vallásszociológusok szerint a reformáció egyik nagy eredménye az volt, hogy ösztönzően hatott az általános műveltségre, mivel a hozzá füződő teológia azt hangsúlyozta, hogy „minden hívo önmaga is prédikátor” (Hargrove 1971: 157-158). Az egyéni vallásos meggyőződés így levált az egyház intézményéről $s$ ezzel lehetővé vált az egyén számára, hogy önmaga is hozzáférhessen a Szentíráshoz. Az egyén szerepének hangsúlyozásával a reformáció szellemisége előkészítette a humanizmus térnyerését. A felvilágosodás és a francia forradalom mellett, a reformáció is kellett ahhoz, hogy kialakuljon az egyén fogalma, ami megalapozta a tudomány, oktatás és gazdaság fellendülését és magával hozta a szekularizációt is. A protestantizmus átrajzolta Európa vallási térképét azáltal, hogy plurális vallási kultúrákat hozott létre és ennek a folyamatnak az eredménye az is, hogy a társadalmon belül eltolódtak a vallásosság és világiasság közötti határok. A reformáció hozadéka volt az európai vallásosság sokszínűvé válása, a különböző nemzetállamok különféleképpen fonódtak össze az egyházakkal, valamint más felekezetekkel és hitéleti gyakorlatokkal. Miközben Európa déli területei megmaradtak katolikusnak, addig a három skandináv királyságban, Dániában, Norvégiában és Svédországban és bizonyos mértékig Észtországban és Lettországban, vagyis a Baltikumban; éppen úgy, mint Németországban és Angliában, a lutheri tanok honosodtak meg és ezek a területek mind a mai napig megőrizték a lutheránus vallási örökséget. A skandináv-balti országokban a reformátusok száma eléri a közel 30 milliót. Az evangélikus-lutheránus egyházak a skandináv térségben úgy nevezett népegyháznak. Ez pedig korábban azt jelentette, hogy tulajdonképpen a „népek egyházának” tekintették őket. A skandináv evangélikus-lutheránus egyházakat különféle népek alkotják, ezért a reformáció a gyakorlatban a különféle államokhoz kötődő, külön egyházak kialakulását eredményezte. (Rémond 1999: 19-23.)

A lutheri reformáció egy olyan új vallásos kultúrát hozott létre, mely épp annyira igyekezett megkérdőjelezni az isteni kegyelem, az üdvösség fogalmaira, valamint a kolostori fogadalmakra, a szentek tiszteletére valamint az ereklyékkel való kereskedésre épülő katolikus hittételeket és gyakorlatokat, mint amennyire megkövetelte, hogy az emberek fokozottabb mértékben szóljanak bele a világi dolgokba. Ötszáz éves történelme során a lutheránus egyház az állammal közösen nagyobb mértékben meghatározta vallási értelemben az egyént és szorította korlátok közé annak szabadságát a skandináv lutheránus társadalmakban, mint ahogyan a katolikus egyház tette azt Európa déli területein. Mindennek a magyarázata a lutheri teológiában keresendő, habár talán Luther eredeti szándéka nem ez volt. Luther szerint Jézus Krisztus isteni természetét ugyanis nem az emberre jellemző természetes tulajdonságokkal szembe állítva, hanem éppen azokkal párhuzamban kell felfognunk. Luther Jézus Krisztus természetes voltát hangsúlyozta és amellett érvelt, hogy az evangéliumok nem adnak számot Krisztus minden cselekedetéről. Úgy vélte, hogy Jézus, legyen bár Isten egyszülött fia, mégis csak egy egyszerű ember volt, teljes fizikai valójában, s ehhez bizony még a székelés is hozzátar- 
tozott. „Minden bizonnyal többször imádkozott, böjtölt, járt az árnyékszékre, prédikált és tett csodákat, mint ahányszor ezt az evangélium említi (idézi: Roper 2016: 176).

Luther édesapja bányászattal foglalkozott és a teológus ebből a közegből kölcsönözte azokat a hasonlatokat, melyekkel az Isten és az ember közötti viszonyt szemléltette. A fémek megolvasztását használta például képként akkor, amikor azt kívánta megvilágítani, hogyan is jött a világra Krisztus Szűz Máriától. A kovács üllojjére helyezett izzó vörös fém egyszerre vas és tűz. Az ember Istennek gyarló (vagyis testtel bíró és testet öltött) teremtménye, ezért egyszerre bűnös és isteni. Az egyén lelkiismerete az, amely közvetlenül kapcsolatban áll Istennel. Luther a lelkiismeretet érzelmek bonyolult összességeként fogta fel, melyet a szív és az értelem együttesen határoz meg és így ez a kölcsönhatás különféle érzelmi állapotokat eredményez, mint például bánat, gondterheltség, szomorúság, vidámság, boldogság, nyugodtság, gyengeség, szilárdság vagy bátorság (vö.: Roper 2016: 165; 183-184).

\section{Az állami lutheranizmus megszületése a svédek és finnek lakta területeken}

A XVI. század végére (hivatalosan 1593-ra) a lutheranizmus az állam kormányzásának részévé vált és meghatározó hatalommal bírt a Svéd Királyságban (vö.: Markkola 2015: 4). A reformáció után, I. Gusztáv király elkobozta azokat a birtokokat, melyek korábban a katolikus egyház és a monostorok tulajdonát képezték. Továbbá minden egyházi méltóság kinevezéséről a király döntött és az uralkodó korlátozta az egyházmegyékben a püspökök és a káptalanok jogait (Hiljanen 2017: 195). A reformáció lehetőséget kínált a királynak arra is, hogy komoly mértékben csökkentse ne csak a püspökök, hanem más egyházi méltóságok támogatását és növelje ezzel a királyi udvar bevételeit és ezzel pedig saját valamint a nemesség érdekeit is szolgálja. Kezdeti szakaszában a svédországi reformáció inkább volt politikai természetű mintsem vallásos átalakulás. Birtokainak és bevételeinek elvesztése súlyos nehézségeket okozott az egyháznak, amely korábban fontos szerepet töltött be a szegények és betegek megsegítésében és a tehetséges ifjak felsőfokú tanulmányainak támogatásában is. A birtokok és egyéb javak elkobzása után az egyház már nem volt képes arra, hogy ezeket a korábbi tevékenységeit folytassa. Svédországban megszűntek a kolostorok és ez érintette a turkui érsekséget is, melynek területe napjaink Finnországának felel meg, ezzel a reformáció a kolostori iskolák végét jelentette. A reformáció és a megcsappant egyházi bevételek ilyen formán megnehezítették a helyi egyházi iskolák helyzetét, mivel a plébániák bevételei jelentösen csökkentek (Salonen 2018: megjelenés előtt).

Ezek a folyamatok érintették a turkui székesegyház iskoláját is, melynek vezetője a finn református Mikael Agricola volt. Agricola 1536 és 1539 között Wittenbergben Luther Márton és Phillipp Melanchton tanítványa volt és jelentős hatást gyakorolt rá ezzel egy időben az európai humanizmus kiemelkedő alakjának, Rotterdami Erasmus- 
nak a munkássága. Mikael Agricola megteremtette a finn irodalmi nyelvet, ugyanis 1543-ban megjelentette Ábécéskönyvét. Tette mindezt öt évvel az után, hogy például Dévai Bíró Mátyás Magyarországon megírta és kiadta az első magyar nyelvű grammatikát (Kontler 1999: 154). Agricola és Dévai Bíró diáktársak voltak a Wittenbergi Egyetemen és mindketten ugyanazon az úton jártak, vagyis Luther vallásos mozgalmát az anyanyelvük segítségével igyekeztek előremozdítani. A katolicizmusból a protestantizmusba való átmenet csak úgy, mint Észak-Németországban, Magyarországon vagy Svájcban, a skandináv térségben is gyökeres változásokat hozott magával az oktatás és az írni-olvasni tudás tekintetében. A finnek lakta területeken szintén visszhangra talált a lutheranizmus azon törekvése, mely az anyanyelv szerepét hangsúlyozta. Az anyanyelv jelentősége megnőtt; a vallás és a műveltség nyelvévé vált. Svédország keleti vidékén, melyből később kialakult Finnország, három írott nyelv létezett a középkorban: az egyházi élet nyelve a latin volt, a jogi és közigazgatási ügyeket svédül intézték és a kereskedelemmel kapcsolatos levelezés pedig a Hanza-szövetség közvetítő nyelveként használt középalnémet nyelven folyt. A finn nyelvet ezzel szemben nem használták írásban, vagy legalábbis erről nem maradt fenn bizonyíték, eltekintve egy-egy finn hely- vagy személynévtől, mely valamilyen más nyelvü iratban bukkan fel. Agricola munkája, az úgynevezett $A B C$-kiria ötvözi az ábécéskönyv és a katekizmus müfaját. A könyv az ábécé betűivel kezdődik, majd bevezeti az olvasót a keresztény vallás alapjaiba (tartalmazza Tízparancsolatot, az Apostoli Hitvallást, a két legfontosabb imádságot; a Miatyánkot és az Üdvözlégyet; elmagyarázza a keresztelés, gyónás szentségét, szól az Oltári Szentségről és felsorol reggeli, esti és étkezésekhez kapcsolódó imádságokat, valamint említi a harangozást is). A könyv a számnevek leírásával zárul (Salonen 2018: megjelenés előtt).

A finn helyesírás első szabályait Agricola fektette le, 1544-ben lefordította az Imádságok könyvét, 1548-ban az Újszövetséget és 1551-ben pedig Dávid zsoltárait. Munkásságát Agricola egy olyan történelmi időszakban fejtette ki, amikor a katolicizmusból a lutheranizmusba való vallási átmenet egyre inkább megmutatkozott az egyházi közigazgatás újraszerveződésében és az egyház tevékenységeiben. 1548-ban I. Gusztáv király kérésére le kellett mondania a turkui székesegyház iskolájának vezetéséről. Ennek oka talán az lehetett, hogy a finn reformátor korábban bírálta a királyt azért, mert az úgy döntött, hogy csökkenti az iskola és Agricola hivatalának támogatását. 1554-ben azonban mégis őt nevezték ki Turku püspökének (Episcopus Aboensis) és a király 1557ben Moszkvába küldte azért, hogy békekötésről tárgyaljon, mivel az ország keleti határvidékein a Svéd Királyság és Oroszország között folyamatos viszályok dúltak. Az utazás megviselte Agricola egészségét és a visszaúton 1557. április 9-én halálát lelte a Karjalai-szorosban. Mikael Agricola sírhelye Vyborg városában található, amely 1944-ig, a téli háborúként is ismert, finn-szovjet háború végéig Finnország része volt. (Heininen 2007: 127-142).

Úgy tartják, hogy Svédország vallási tekintetben ingadozott: hol katolikus, hol kálvinista és lutheránus volt a reformáció által előidézett vallásos átrendeződés közepette. I. Gusztáv király legidősebb fia, XIV. Erik király a kálvinista hitet támogatta, miközben 
a másodszülött fiú, a későbbi III. János király pedig a katolikusok pártjára állt azt követően, hogy a lengyel Jagelló Katalint vette feleségül. Zsigmond fiuk, akit 1593-ban Svédország és Lengyelország királyává koronáztak, katolikus nevelést kapott, ugyanakkor nem kérdőjelezte meg, hogy Svédországban az állam által hivatalosan elismert vallási irányzat a lutheranizmus. A pápa azonban III. Zsigmondnak azt a feladatot adta, hogy állítsa vissza a katolicizmust Svédországban. I. Gusztáv király legkisebb fia, Károly herceg lutheránus volt. A fivérek eltérő vallási neveltetése és szemlélete viszályt váltott ki: Károly herceg miután csatában legyőzte unokaöccsét Zsigmond királyt megalapította a protestáns Svéd Királyságot, melynek IX. Károly néven 1606-ban lett királya és uralkodása 1611-ig tartott. A Zsigmond és IX. Károly közötti hatalmi harcban döntő szerepet játszott a Svéd Királyság keleti országrésze, ahol a mai Finnország található. A történészek szerint Finnország katolikus ország maradt volna, ha Zsigmond elég erős ahhoz, hogy nagybátyja IX. Károly ellenében megőrizze hatalmát. A kutatók feltételezik azt is, hogy Zsigmond célja valószínűleg az lehetett, hogy érvényesítse a pápa akaratát, vagyis egyesítse és katolikussá tegye a finn és lengyel területeket. IX. Károly győzelmével azonban egy olyan teokrácia alakult ki, mely a lutheránus ortodoxia korszakát hozta el. (Lappalainen 2014: 31-34; Hiljanen 2017.)

\section{Szociáldemokrácia mint a lutheranizmus új formája?}

A politikai gazdaságtan amerikai professzora Robert $\mathrm{H}$. Nelson, aki a történelem változásait is figyelemmel kíséri, a skandináv országok kultúráját és társadalmát vizsgálva írta meg Lutheranism and the Nordic Spirit of Social Democracy [A lutheranizmus és a szociáldemokrácia északi szelleme] (2017) című könyvét. A kötet címe Max Weber jól ismert tanulmányára utal, melynek címe: A protestánst etika és a kapitalizmus szelleme. Robert H. Nelson a következő két megállapítást teszi ebben a munkában: 1. a skandináv országok lakosságának beállítottságát alapvetően még napjaink modern világában is többségében a lutheránus szellemiség határozza meg és 2. a szociáldemokrácia tulajdonképpen a lutheranizmus világi változatát testesíti meg. Függetlenül a világszerte tapasztalható szekularizációtól valamint azoktól a kihívásoktól, melyeket a pietizmus vagy más újabb vallási kezdeményezés jelentett vagy jelent; Nelson szerint a lutheránus erkölcsiség soha nem tủnt el. Weber állításaival szemben Nelson úgy gondolja, hogy nem létezett olyan protestáns etika, mely a teljes protestantizmust magába foglalta volna. A lutheránus erkölcsiség másképpen viszonyul a kapitalizmushoz, mint ahogyan a kálvinizmus teszi. Nelson azt hangsúlyozza, hogy a tudomány nem mutatott érdeklödést a lutheránus erkölcsiség iránt, amikor azt vizsgálta, hogy a reformáció milyen módon formálta és hozta létre a huszadik században a jóléti államnak azt a formáját, mely a skandináv térségben „a társadalom világi üdvösségeként” értelmeződik (Nelson 2017: 41). A lutheránus etika egy olyan szilárd alapot és irányadó szellemiséget jelentett, mely a skandináv térségben a szociáldemokrácia huszadik századi politikai és gazdasági sike- 
rének feltétele volt. A skandináv térség jóléti államai átértelmezték és kisajátították a lutheránus erkölcsiséget, mely aztán a szociáldemokráciában jutott kifejezésre (Nelson 2017: 12; 37-52).

Nelson merész következtetéseket von le a skandináv országok politika-, gazdaságés vallástörténetéből. Az viszont más kérdés, hogy ezek a következtetések történelmi és módszertani szempontból vajon megállják-e a helyüket. Azok az értékek, melyeket a Gallup Ecclesisastica címmel 2015-ben megjelent felmérés lutheránus jelzővel illet, mind megtalálhatóak a jobb- és a baloldali pártok programjaiban egyaránt. Ilyen értékként jelenik meg az, hogy az emberek fontosnak tartják, hogy másokon segítsenek, osztozzanak a társadalmi felelősségben és elkötelezettek legyenek a munka és az oktatás iránt. A sajátosságot az adja, hogy ezeket az értékeket nem hozzák kapcsolatba Istennel és az istendicsérettel, énekekkel. Módszertani szempontból Nelson érvelése az implicit vallásosságon alapul (Nelson 2017: 269). Habár nem jelöli ki egyértelműen, hogy milyen elméleti keretben értelmezi a vallás fogalmát, mégis az alapvetése a következő: bármely szervezett társadalmi tevékenységet értelmezhetünk vallásként - még akkor is, ha az ilyen tevékenységet gyakorlók közössége Durkheim értelmezésében nem alkot egy egyházat. Ennek az értelmezésnek elégséges feltétele pedig az, hogy az adott tevékenység közvetve az üdvösséghez vezessen, vagyis egyfajta fejlődést idézzen elő $s$ így megszabadítson a gonosztól és a haláltól (melyek az élet és a haladás kerékkötői). Nelson szerint a marxizmust, szocializmust és a (keynesi) közgazdaságtant is vallásnak lehet tekinteni. Vagyis a skandináv térségben egy olyan átmenet zajlott le, amely az emberek, a társadalom és a jóléti államot szolgálja és amely a lutheránus istenhitről egyfajta közgazdasági értelemben vett vallásosságra való áttérésként írható le. (vö.: Nelson 2017: 198; 268-284).

Milyen további hozadéka van tehát annak, ha a vallás fenti értelmében azt vizsgáljuk, hogy milyen hatással volt lutheránus vallási örökség a belső politikai kultúra kialakulására a skandináv térség országaiban? Vajon a Nelson által meghatározott „közgazdasági teológia” például értelmezhetö-e Svédország esetében? Két svéd történész professzor, Henrik Berggren és Lars Trägårdh Är svensken människa? Gemenskap orch oberoende $i$ det moderna Sverige [Emberek-e a svédek? A radikális individualizmus a szociális szolidaritás államában] címmel 2006-ban egy közös kötetet jelentetett meg a témában. A szerzők abból indulnak ki, hogy óriási tévedés azt gondolni, hogy a svéd politikai kultúrának ne lenne semmilyen köze a vallásos meggyőződéshez. A tanulmánykötet 2017-ben napvilágot látott második kiadását egy új fejezettel egészítették ki, ennek címe En luthersk modernitet [Lutheránus modernitás] - ezzel szerették volna az első kiadás hiányosságait kiküszöbölni. A történelmi adatokkal Berggren és Trägårdh azt támasztja alá, hogy a 20. század hajnalán a svédországi munkásosztály ellenségesen viseltetett a kereszténységgel szemben. Finnországban ugyanez volt a helyzet. A svéd állami iskolákban 1919-ben végrehajtott tanügyi reform során a szociáldemokraták a keresztény tankönyveket lecserélték és helyettük a Värner Rydén Medborgarkunskap 
[Állampolgári ismeretek] (1923) című munkáját tették kötelező olvasmánnyá a fiatalok számára (Berggren and Trägårdh 2017: 383). Berggren és Trägårdh tulajdonképpen azt mutatják be közös munkájukban, miképpen szorította ki a svéd állam és egyház közötti viszony osztályharcon alapuló értelmezését egy új megközelítés az 1930-as évek első felében, amikor ismét a szociáldemokraták adták az ország miniszterelnökét. Miközben a korábbi törekvés még az volt, hogy felszámolják az államegyházat, addig az új kezdeményezés azt tüzte ki célul, hogy egy új szövetséget hozzon létre a Ungkyrkorörelsen elnevezésű lutheránus szellemiségü, újvonalas egyházi mozgalom és a szociáldemokrata párt között. Ennek a kezdeményezésnek svédül a folkhemmet, azaz a nép otthona nevet adták és még jóval azelőtt megjelent ez az elképzelés, hogy a szociáldemokrata miniszterelnökök Per Albin és Tage Erlander 1932 és 1969 között ezt az elképzelést meghonosították volna a svéd politikai életben (Berggren and Trägårdh 2017: 208-211; 385). A folkhemmet fogalmát megelőzően létezett már a folkkyrka, vagyis az nép egyháza kifejezés, amelyet rendszerint a lutheránus egyházak megnevezésére használtak a skandináv térségben, és amely az államegyháztól a népegyház intézménye felé történő elmozdulást jelezte. A folkhemmet egy mélyreható reformtörekvés volt, mely a svéd egyházat kívánta átalakítani úgy, hogy az mint társadalmi intézmény elfogadhatóbbá váljon a munkásosztály számára. Nathan Söderblom, aki később a vallástörténet professzora lett és a svéd egyház (Svenska kyrkan) érsekeként is tevékenykedett, egyik korai képviselője volt az említett újvonalas egyházi mozgalomnak. Söderblom ökumenikus szellemiségű hazafi volt, aki arra törekedett, hogy a mozgalom ideológiai értelemben eltávolodjon a svéd vallási nacionalizmustól (ett Gods folk) és e szemlélet helyett a kereszténység egész világra kiterjedő, átfogó küldetését tegye magáévá (Berggren and Trägårdh 2017: 384-385).

Berggren és Trägårdh legfőbb megállapítása az, hogy Svédországban a társadalmi szerződés jelentős mértékben különbözik attól, amit más modern, nyugati demokráciákban megfigyelhetünk. Svédország egyedülálló abban a tekintetben, hogy milyen fontosságot tulajdonít az egyénnek. Ez azonban nem olyan individualizmus, mely önimádatot vagy önzést jelentene, hanem egyfajta „állami individualizmus”, azaz az egyén olyan döntési szabadsága, melyet az állammal való függőségi viszony határoz meg. Az állam és az egyén között ezért bensőséges viszony áll fenn. A svédek azért hagyatkoznak a jóléti államra, hogy az rokonságuktól és saját legszűkebb értelemben vett családjuktól függetlenítse őket. Azért tartják olyan fontosnak azt, hogy függetlenek legyenek a családi kötelékektől és a társadalmi elismerés hagyományos formáitól, mert számukra az állam egy alapvető biztonságérzetet nyújt. A svédek értékszemlélete gyökeresen különbözik attól, amit például Németországban vagy az Egyesült Államokban láthatunk. A World Value Survey, a különféle országok értékrendjét is nemzetközi szinten vizsgáló felmérés szerint a svédek az európai országok mezőnyében leginkább elfogadóbbak a válással kapcsolatban. A svédek rugalmasak és nem félnek változtatni az életükön: művelődnek, munkahelyet váltanak, egyik városból a másikba költöznek, felbontják a 
házasságukat, gyereket vállalnak anélkül, hogy abban a családjuk, munkatársaik vagy barátaik segítségére szorulnának, mivel tudják, hogy van egy olyan finoman hangolt szociális ellátó rendszer, amely megvédi őket (Berggren and Trägårdh 2017: 84).

Még akkor is, ha fenntartásokkal kell viseltetnünk a nemzeti jelleget hangsúlyozó szakirodalommal szemben $s$ jóllehet az ilyen szakirodalomban használt antropológiai és mentalitástörténeti fogalmak kérdéseket vetnek fel, most mégis a svéd szellemiségről Svensk mentalitet címmel készített összehasonlító etnológiai kutatás meglátásait szeretném idézni. A munka a néhai svéd etnológia professzor Åke Daun (1989) nevéhez füződik, aki szerint a svéd társadalomban jelen van egy olyan cél, amely arra készteti az embereket, hogy küzdjenek saját függetlenségükért (självständighet, oberoende) még akkor is, ha ennek végül az ára az, hogy magányosak lesznek. A svédek hajlamosak kerülni a nézeteltéréseket, a kompromisszumot keresik. Igyekeznek visszafogni indulataikat a társas érintkezéseikben. Arra a kérdésre, hogy elveszítik-e türelmüket, ha nem kapják meg azt, amit akarnak, a svéd válaszadók csupán 19 százaléka adott igenlő választ. Ezzel szemben a finnek esetében ez az arány $31 \%$ volt. A nemek közötti különbségek még ennél is szembetűnőbbek voltak. A svédek többsége, egész pontosan 60 százaléka, helytelenítette azt, ha valaki nem mond igazat. Ezzel összevetve a dánok 13, finnek 22 és a norvégok 38 százaléka találta elfogadhatatlannak, ha valaki hazudik. Az élvezeteket a svédek nem tartják tiltott dolognak, viszont csak akkor, ha az élvezetek „föleg rövidebb szüneteket jelentenek, vagy pedig a munkához szükséges feltöltődést szolgálják”. A skandináv térség gondolkodásmódját két fontos tényezővel magyarázzák: az egyik az éghajlat, a másik pedig a lutheránus szellemiség. Az éghajlati tényező alatt a hőmérséklet, a tél és nyár; a hideg és meleg, a világos és sötét évszakok váltakozásának valamint a napfénynek, szélnek és esőnek az emberek hangulatára gyakorolt hatásait szokás érteni. A lutheranizmussal pedig az északi népek puritán, kötelességközpontú világlátását szokás magyarázni, valamint azt, hogy az itt lakók befelé fordulnak és nehezen nyílnak meg mások előtt. A lutheránus puritanizmust szokás megjelölni annak magyarázatként, hogy az emberek miért érzik magukat bűnösnek, miért vádolják magukat. A túl sok élvezet feléleszti a büntudatot az emberekben. A kvantitatív elemzéseken a lutheranizmussal indokolják általában, hogy miért függ olyan szorosan össze a lutheránus erkölcsiség azzal, hogy az emberek nagyra értékelik a kitartó munkát, a hatékonyságot és a rendet (Daun 1987: 56-210).

A skandináv térségből érkező bevándorlók, akik például az Egyesült Államokban vagy Ausztráliában telepednek le, nemzeti identitásukat úgy juttatják kifejezésre, hogy azzal egyszerre utalnak velük született/ hazájukból hozott hagyományaikra és lutheránus gyökereikre. A finneket bárhová is sodorja a sorsuk, bárhol is telepedjenek le, rendszerint az életük fontosabb eseményeihez kapcsolódóan létrehoznak két olyan dolgot, amellyel megkülönböztetik magukat a helyi lakosságától: ez a két dolog pedig nem más, mint a szauna és a lutheránus egyházközösség. Ronald Bordessa amerikai antropológus a társadalmi valóság szempontjából leginkább a lutheranizmust tartja hangsúlyosnak 
Finnországban. Az egyén lutheránus felfogásának meghatározó jelképe a finnek esetében az erdős táj. A finn lutheranizmusban az egyén a háborítatlan erdőségek és sziklás vidékek terében bontakozhat ki, vagyis olyan kijelölt helyeket tartanak fontosnak, melyek az érintetlen természetet jelenítik meg és melyek révén az isteni akarat közvetlenül, az egyház hivatalai, tisztviselői nélkül, szólíthatja meg az egyén lelkét. Bordessa úgy véli, hogy a finnek azért élik meg olyan erősen a nemzeti összetartozás érzését, mert befelé, saját otthont jelentő környezetük felé fordulnak (Bordessa 1991: 90).

Nem csupán a skandináv térség nemzetállamai estek át változásokon az elmúlt öt évszázad során, hanem a református kereszténység is. Nem változott azonban az, ahogyan az emberek a vallásosság és világiasság közötti határokat meghúzzák - tekintsük az emberekre akár egyénként vagy valamilyen társadalmi szerveződés részeként. Ugyancsak változatlan az is, ahogyan cselekedeteiket az általuk szentnek tekintett értékekre alapozzák. A lutheranizmus a skandináv térség országaiban a történeti fejlödés eredménye, ami azt is jelenti, hogy lényege mindig attól függ, hogy mely sajátosságait tartunk lényegesnek. Az egyházak mint a társadalom intézményei soha sem állandó módon szemlélik a múltat, s még inkább változó a szemléletük, ha az előttünk álló jövőről van szó.

\section{Irodalomjegyzék}

Berggren, Henrik och Lars Trägårdh 2017. Är svensken människa? Gemenskap och oberoende I det moderna Sverige. Stockholm: Norstedts.

Bordessa, Ronald 1991. The Iconic Self: Luther, Culture, and Landscape in Finland. In: Sacred Places and Profane Spaces. Essays in the Geographics of Judaism, Christianity, and Islam, 81-92. Edited by Jamie Scott \& Paul Simpson-Housley. Westport, CT: Greenwood Press.

Daun, Åke 1989. Svensk mentalitet. Ett jämförande perspektiv. Simrishamn: Rabén \& Sjögren.

Goldstein, Warren S. 2009. Secularization Patterns in the Old Paradigm. Sociology of Religion 2009, (2): 157-178.

Hargrove, Barbara W. 1971. Reformation of the Holy. A Sociology of Religion. Philadelphia: F. A. Davis Company.

Heininen, Simo 2007. Mikael Agricola. Elämä ja teokset. Helsinki: Edita.

Hiljanen, Mikko 2017. Servants of the Crown or Trustees of the People? Personal Agency Among the Local Clergy (1550-1610). In: Personal Agency at the Swedish Age of Greatness 1560-1720, edited by Petri Karonen, \& Marko Hakanen. Studia Fennica Historica 23, 194-216. Helsinki: Finnish Literature Society.

Ketola, Kimmo; Hytönen, Maarit; Salminen, Veli-Matti; Sohlberg, Jussi \& Sorsa, Leena 2017: Luthersk delaktighet: Evangelisk-lutherska kyrkan i Finland 20122015: En undersökning om kyrkan och finländarna. (Kyrkans forskningscentrals 
publikationer, 126) Tammerfors: Kyrkans forskningscentral. URL http://sakasti. evl.fi/sakasti.nsf/0/4D9073DDB9C38745C22576F20030A70E/\$FILE/Kirkon_ nelivuotiskertomus_II_osa_Luthersk_delaktighet_verkkojulkaisu-1.pdf.

Kontler, László 1999. Millenium in Central Europe. A History of Hungary. Budapest: Atlantisz.

Laine, Esko M. 2007. Luterilainen ortodoksia. In: Suomen historian kartasto. Päätoimittaja Pertti Haapala. Toimittaja Raisa Maria Toivo. Karttakeskus, 138-139.

Lappalainen, Mirkka 2014. Pohjolan leijona. Kustaa II Aadolf ja Suomi 1611-1632. Helsinki: Kustannusosakeyhtiö Siltala.

Markkola, Pirjo 2015. The Long History of Lutheranism in Scandinavia. From State Religion to the People's Church. Perichoresis 2015, 13 (2): 3-15. De Gruyter. Open Access. URL https://www.degruyter.com/view/j/perc.2015.13.issue-2/perc-20150007/perc-2015-0007.xml.

Nelson, Robert H. 2017. Lutheranism and the Nordic Spirit of Social Democracy. A Different Protestant Ethic. Aarhus: Aarhus University Press.

Rémond, René 1999. Religion and Society in Modern Europe. Oxford: Blackwell Publishers.

Roper, Lyndal 2016. Martin Luther. Renegade and Prophet. London: Vintage.

Salonen, Kirsi 2018. Reformation and the Medieval Roots of the Finnish Education. In: Kaius Sinnemäki, Anneli Portman, Jouni Tilli, and Robert H. Nelson (eds.), On the Legacy of Protestant Lutheranism in Finland: Societal Perspectives (Studia Fennica Historica). Helsinki: Finnish Literature Society. Forthcoming.

Talve, Ilmar 1997. Finnish Folk Culture. Studia Fennica Ethnologica 4. Helsinki: Finnish Literature Society. 